\title{
From the Black Death to the New World (c.1350-150o)
}

\author{
Philipp Robinson Rössner
}

The history of objects is now a fashionable new subdiscipline within the academic discourse in history. ${ }^{1}$ This resulted from the eminently trivial yet, in the age of the so-called Cultural Turn, probably overemphasized insight that written records never tell us the full story. Stories they certainly tell, but these may be biased either by omission or incorrect depictions of factual reality (with factual reality being a questionable epistemic proposition in itself). They may be ambiguous and sometimes plain wrong. A lot of human activity, experiences, agency, and feelings cannot and has not been covered in written sources. For these reasons, it is commonly accepted that objects represent a valuable, in many ways indispensable way of mining and corroborating information from the human past that would otherwise be left unknown, if the historian would limit her or himself to an examination of the written record only. But since objects "speak" a language and through channels different from written records, accordingly they require their own technique of decoding.

Rarely has this history been written or the call by the history-of-objects faction been heeded from the vantage point of money, more specifically coins, through the discipline of decoding them as historical media or transmitters of information, generally called numismatics. This is odd, since money and coins represent a very obvious starting point for writing such a history, perhaps even more obvious than other fashionable subjects of study which modern exponents of object-based history have been so fascinated about in recent

1 The history of objects was made popular by a blockbuster 2012 book: MacGregor, A History of the World in 100 Objects. A good example from economic and world history comes from Riello, Cotton. See also the long introduction in Appadurai, The Social Life of Things; Harvey, History and Material Culture, esp. the chapter by Giorgio Riello; Grassby, "Material culture and cultural history"; Kingery, Learning from Things; Attfield, Wild Things; Johnson, An Archaeology of Capitalism; Mehler, "The archaeology of mercantilism”, which combines an archaeologist's viewpoint on tobacco pipes with the problem of 18th-century political economy in the German-speaking lands; Hoskins, "Introduction"; Findlen, Early Modern Things; Hamling and Richardson, Material Culture and Its Meanings; and Ago, Gusto for Things. On money specifically, from an anthropologist's viewpoint, see Hart, "Heads or tails?" 
years, such as Martin Luther's garments, early modern bedsheets, or cotton. ${ }^{2}$ For nearly three millennia nearly all societies across Eurasia (and beyond: just consider China or India) have used some sort of money. And most of the time this money was in the shape of coins, ever since this invention or technique was adopted almost simultaneously in various areas of Europe and beyond, from the Aegean around 700 B.C. to China. ${ }^{3}$

\section{Background}

Not much would change in all the years after coined money can be first identified from the archaeological record. From the 8th century B.C. until the end of the 19th century most coins would contain at least some precious metal. For the best part of these $c .2,6$ oo years people would entertain the idea that not only should money express value, but this value should be reflected in the value of the materials embodied in coins. For monetary history, labels such as "antiquity", "medieval" (or early/late medieval), or "early modern" make even less sense than they do for general or mainstream history; there was no change of fundamental significance between 700 B.C. and A.D. 1900 in terms of either the physical appearance of money and coins or some of the basic ideas and theories entertained about them. But there were changes over time, if very gradual and piecemeal and much less pronounced than the grand political and social changes usually associated with landmark events such as the French Revolution, the Reformation, and the Black Death. As regional economies in Europe moved towards capitalism - northern Italian cities did so beginning in the 120os, other regions much later - more and more commodities and human actions became subject to the market principle. Accordingly, this prompted an increased need for cash. Prices for foodstuffs were subject to fluctuations over time, expanding in the long term due to commercial affluence between the 11th and 14th centuries (halted partly by the Black Death, partly by the abnormal climatic conditions of the 1310s), then declining in the wake of the epidemic and the 15th-century integration crisis of the Renaissance, only to expand again thereafter, giving way to, from the 1530 and 1540 , the age of the great inflation or "Price Revolution." Once again, such cycles can be associated with changes in the overall demand for money and cash as a means of transaction, as during times of inflation the European population, and thus economic

2 See, e.g., Rublack, "Matter in the material Renaissance"; Handley, Sleep in Early Modern England; or Beckert, Empire of Cotton.

3 Von Reden, Money in Classical Antiquity. 
activity as a whole, grew (contracting at times of low prices and depression). Thus the price level marks the "rhythms" of the European regional economies.

If we were to pinpoint the main markers of change, we could say that a wave of monetary innovation first came in the 13th century with the introduction of large silver coins (solidi, shillings) and even more valuable coins made of gold (fiorini, florins). Thereafter no major changes took place until long after the Black Death, when the age commonly called either the "late Middle Ages" or "Renaissance" would be associated with times of crisis in many market economies, and accordingly low prices. Such times saw an increase in the purchasing power of existing moneys, but also reflected, partly at least, a scarcity of silver as the main monetary metal. ${ }^{4}$ Then the onset of the price inflation after the 1470 s and the boom in the central European mining industry set the pace for a new run of silver mining and the minting of a new heavy silver coin equal in purchasing power, and up to the task formerly fulfilled exclusively by the gold florin. Thus the monetary history of the late Middle Ages is marked by oscillation between the two poles of crisis/high silver price, as well as inflation and the gradual need to refill the European monetary landscape with new types of coin, particularly the silver florin or taler.

Students wishing to consult the vast literature should be aware that there are divides between monetary history and numismatics as a technical discipline or historical-auxiliary science (Hilfswissenschaften in German), and between monetary and economic history and straight economics. Many economists have written on the history of money by applying modern concepts to the rich and varied European evidence. Among the works that cross the boundaries between history and numismatics, Peter Spufford's Money and Its Use in Medieval Europe is justly considered to be a classic. Students wishing to learn more about numismatics are referred to Philip Grierson's Numismatics or, for those possessing a basic level of German, to Niklot Klüßendorf's outstanding yet very concise and neatly framed Münzkunde (2009). John Day's classic article in Past

4 About the nature, coverage and extent of such a "crisis" of the $15^{\text {th century there has been }}$ much debate. See, e.g., Miskimin, "Monetary movements and market structure" and The Economy of Later Renaissance Europe; with Cipolla, "Economic depression of the Renaissance?" for a different viewpoint. For northern Germany, the study by North, Geldumlauf und Wirtschaftskonjunktur, has established some incontrovertible evidence of economic contraction. A numismatist's viewpoint that supports this notion is presented in the classic article by Day, "The great bullion famine of the fifteenth century" and "The question of monetary contraction in late medieval Europe". A recent quantitative overview and discussion is presented in Munro, "The monetary origins of the 'price revolution'", as well as in Mayhew, "Prices in England". On the depression in the late medieval European mining economy, see Westermann, "Zur spätmittelalterlichen Depression der Montanwirtschaft". 
\& Present on the great medieval "bullion famines" sets out the framework for a monetary historian's framing of the Middle Ages with ample recourse to coins, money, and numismatic evidence, while Nicholas Mayhew's and Martin Allen's studies give an excellent introduction to late medieval money in England. For the continental moneys, apart from Spufford, the works by Michael North are excellent (but unfortunately only available in German).

Coins of this period were made from precious metal. The near-complete virtualization of money by bank giro (direct transfer), draft and deposit banking, the use of credit cards and IT technology, etc. came later, albeit elements of it were known after the "invention" of the bill of exchange as a means of cashless payment came in the wake of the northern Italian commercial revolution of the 12th and 13th centuries. ${ }^{5}$ Often based upon coins and an existing system of money and payment of coins, instruments of cashless payment and credit were known since the earliest days but did not normally exist a priori or independent of one particular type of coin-shaped money. One controversial voice has even claimed that credit came before money. ${ }^{6}$ Coins can tell us stories and give us answers which the written record never can or will, due to absence or omission among written sources or simply the different and very specific type of message that coins carry as a cultural messenger, container, and transmitter of information. The following account is limited to a brief survey of what money is and what it looked like in the Middle Ages before the age of discovery. This is followed by an examination of the stories that money can tell the historian, before a brief conclusion points out possible directions for further research.

\section{What is Money?}

To understand medieval money, perhaps the most important thing to do is to shed the modernist understanding of it, beginning with the first of the modern myths. It has been popular folklore among economists that money originated more or less spontaneously, whenever two or more individuals got together to seal a deal at market and exchanged something that one party wanted but could only produce for her- or himself at large opportunity cost, for another commodity that the other party could produce or procure with much greater

5 On commercial innovation in the Middle Ages, including marine insurance, deposit banking, etc., see Lopez, The Commercial Revolution of the Middle Ages, 950-1350 and Spufford, Power and Profit. On the bill of exchange in particular, see the long introduction in Denzel, Handbook of World Exchange Rates.

6 Graeber, Debt: The First 5,0oo Years. 
ease and efficiency. So, if a shoemaker wanted to eat, he or she might ask the baker to give him some bread. But as one pair of shoes would easily pay for several loaves of bread, and the baker would have no use for just one shoe, nor the shoemaker for ten loaves at once (because the bread would go stale or mouldy before it could be eaten), the theory is that the baker and shoemaker would get together, invent money, and thereby solve all their coordination problems. In this way they would reduce what economists call transaction costs and facilitate exchange. Thus money arose out of the market process based on a market economy and, according to Adam Smith in his Inquiry into the Nature and Causes of the Wealth of Nations (1776), humanity's "natural inclination to truck, barter and exchange." The modern economists' "coincidence of wants" argument goes back to W. Stanley Jevons' classical textbook on money, ${ }^{8}$ but can in fact be found, in similar shape, in many earlier writings even before Adam Smith, including 17th-century German Cameralists and economists such as Johann Joachim Becher (1635-1682), or Veit Ludwig von Seckendorff (1626-1692). ${ }^{9}$ It is at the same time both very compelling and profoundly wrong. Historians agree that money, in the shape of coins, was often created earlier than and sometimes quite independently from a pre-existing market economy. It was "invented" by states, rulers, and "governments" to raise taxes, and if the best way to do so was to establish a market - so be it. Therefore, more often than not, money came first, then the exchange-based or market economy, ${ }^{10}$ not necessarily the other way round as the ideal world of the economists wants to have it.

Hence, in many ways, the modern concept of the definition, function, and purpose of money found in economics textbooks of today, usually based upon the classical introduction by Jevons, is counterintuitive. (We should, however, for reasons of fairness and completeness, remind ourselves that the basic ideas promulgated by - inter alios - Jevons, of money being mainly a means of exchange, storing and denoting value, and facilitating the economic process, go back in spirit to writings by Aristotle.) It tells us more about what money in the Middle Ages was not, and quite a lot about what modern economists think money is (and was). According to the modernist concept, money serves a general purpose as a means of exchange, a means of expressing value, as well as a means of storing value or conserving (transmitting) purchasing power over time (i.e., saving, investment). These are its core or economic "textbook"

7 Book 1, chapter 2.

$8 \quad$ Money and the Mechanism of Exchange, London, 1875.

9 Rössner, "Monetary theory and economic management in continental European economic reasoning, c.1500-190o".

10 Knapp, Staatliche Theorie des Geldes; Peacock, Introducing Money. 
functions. To these may be added money's role as a means of political, economic, and cultural communication. Whenever a ruler strikes a coin with his image on it, the money communicates a political, as well as cultural message to its bearer (if only the ruler's portrait or image). The message says, "I am the ruler and this is my kingdom. On this coin you will find an image of mine." This pictorial message or image is usually accompanied by some sort of regal or royal insignia, a sword, or a cross. In a modern context, where money is usually territorial (or supra-territorial, in monetary coordination and integration schemes such as the euro), the modern reader would expect such a message to go on like this: "Please note that in my kingdom/realm, my money will be the only and exclusively accepted legal means of payment."

But such was not the case in early modern and medieval Europe. At this time, the notion of legal tender in the modern sense - meaning that there should be one legally exclusive currency for each territory - did not exist. Medieval rulers, such as the Saxon dukes and electors, were known to accept many nonSaxon currencies alongside "Saxon" coins in circulation. The result was a bewildering number of edicts and ordinances detailing and sometimes picturing each and every single coin type that was permitted or prohibited. Usually such legislation was meant to be temporary, often for a year (and often tied to market rhythms of the weekly urban markets, quarterly and annual regional fairs, and yearly markets). There was an element of temporality in pre-1850 understandings and models of currency and monetary policy that has vanished from the scene since the development of modern forms of marketing. Accordingly, a fiduciary monetary standard was adopted that decoupled money's extrinsic value or purchasing power from its intrinsic value or material content.

In consequence, until very recently (into the 19th century, in fact) most people in continental Europe used a bewildering variety of currencies and coin types of different sizes, denominations, and origins. Around 1500 in the Holy Roman Empire (Germany) alone, there were about 300 territorial "states" and state-like entities (duchies, counties, abbeys, etc.) whose rulers were entitled to mint their own money, and about 500 mints were known to exist. ${ }^{11}$ Foreign and domestic coins circulated relatively freely and peacefully alongside one

11 Sprenger, Das Geld der Deutschen; Schremmer, "Über 'stabilies Geld' ”. On German monetary history, see further North, Das Geld und seine Geschichte; North, Kleine Geschichte des Geldes; Rittmann, Deutsche Geldgeschichte; Suhle, Deutsche Münz- und Geldgeschichte; Gerhard, "Miszelle"; Gerhard,"Ein schöner Garten ohne Zaun"; Gerhard, "Ursachen und Folgen". Older numismatic works include Friedensburg, Münzkunde und Geldgeschichte and Luschin von Ebengreuth, Allgemeine Münzkunde, as well as von Schrötter, "Das Münzwesen des Deutschen Reichs". 
another. Many rulers were quite happy to have foreign coins admitted as what we would call "legal tender." They (or rather their officials, mintmasters and mint wardens) simply put an official value (spot exchange rate) upon them that would tell people how much one specific foreign type of coin was supposed to be worth in "our money". This process was tariffing by valuation or valvation, as contemporaneous German legal terminology had it.

Far from being limited to denoting financial or economic value, coins since biblical times carried further hidden, deeper meaning. The most obvious reference point was, of course, the Judas treason, which in three of the Gospels (Matthew, Mark, and Luke) involved a specification of the actual means of payment (silver money or aprúpiov). Matthew 26:14-16 even provides a quantifica-

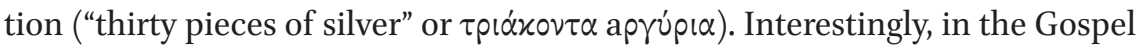
of Judas, a recently discovered apocryphal gospel, the Judas payment is made with "a handful of copper coins", which the Coptic, in which the gospel was written, renders as hkmnt, i.e., the terminus technicus of the Coptic language for copper, rather than silver as we would expect from reading the canonical gospels. Copper, of course, represents small change - and nearly always has in the European context - which fits the overall story better than silver. According to the canonical gospels, only someone like Judas would venerate the money for what it was - a Chrematistic tool directed at enriching himself at the expense of others. Rhodian tetradrachms were venerated as pieces of the original Judas wage all over Europe in the $15^{\text {th }}$ century. ${ }^{12}$ In the Judas Gospel, Judas is seen by some scholars as the "good guy" who betrays Jesus not for the money, but for the sake of implementing, that is, setting in motion, God's ultimate plan of salvation. ${ }^{13}$ This role Judas gets in the overall plan is an infinitely higher reward than any monetary sum would be, be it in silver, gold, or - in the case of small change - copper, which, in this case, is only used in the notional sense: a transaction has been completed, but its monetary value, expressed in copper, is negligible.

Money was (and often still is) also frequently charged with some notion of magic, mishaps, or evil spells as well as, more positively, proliferation and fecundity. This was money's fifth purpose or function: to carry or implement the means of doing magic. Since the earliest times coins were used as relics, cult objects, and objects of veneration; as cures and protection against ill-health, including epileptic spasms and dangerous childbirth.

\footnotetext{
12 See chapter 8, this volume.

13 Ehrman, The Lost Gospel of Judas Iscariot; and Pagels and King, Reading Judas, for an introduction and translation. There are other interpretations by scholars who see Judas, as portrayed in that particular gospel, as a demon.
} 
We also find practices involving the healing power of coins on Good Friday. From the days of King Edward II, and presumably also Edward I, the English kings placed a handful of coins before the Cross of Neith, which was said to have contained splinters of the original cross upon which Jesus had been crucified. Then the king would "buy" them back using ordinary money, in the order of five to 25 shillings, and have them re-smelted into "cramp rings" to be given away as amulets against epileptic strokes. This was no "dark" or black magic but, on the contrary, represented an intrinsic component of Christian practice in northern Europe at the time. Symbolic offerings resulted in the creation of metaphysical value. And the "healing touch" was a commonly accepted quality and proof of a king's superior station in the cosmos of nature as well as the polity or common weal. ${ }^{14}$

Johannes Rothe (1360-1434) related, around 1410, the legend of how coins had originated. Upon the Great Deluge people exchanged their possessions against gold and silver to store value. But upon realizing that the only reliable means of transforming precious metal into a store of silver would be to standardize it, King Ninus had it struck into similar pieces by his skilled smith Terrach, who imprinted the king's image upon them. Later medieval princes would strike coins "in the name of Christ", thus imbuing them with purchasing power according to the State Theory of Money. Of course, coins also feature prominently in northern European folklore and fairy tales, where they were usually related to the creation of wealth in return for a soul promised to the Devil. Coin hoards were often buried near graves or graveyards, which was an effective means of protection and concealment. ${ }^{15}$ As was well known (or assumed), the Devil lurked behind every corner in the graveyard, particularly around midnight; who would be so blasphemous to dare to dig up bones or a treasure at such a foul and dangerous place?

If there is one thing we can be quite certain of, after recent research on the use of coins and particular types or classes of coins and moneys by particular social groups, actors, and classes, ${ }^{16}$ it is that more often than not coined money did not completely fulfil the function of a means of expressing value, because coin value could be debated, negotiated and fought over quite frequently. It accordingly did not always fulfil the criteria of acting as a safe store of value, either. And coined money frequently gave away conflicting messages, more often than not resulting in social conflict, up to the point of social unrest. For

\footnotetext{
14 Bloch, The Royal Touch.

15 Bolte et al., Handwörterbuch des Deutschen Märchens, pp. 465-5o6; Opie and Tatem, $A$ Dictionary of Superstitions, p. 259ff.; and Hiller, Lexikon des Aberglaubens, pp. 72 and 154.

16 Rössner, Deflation-Devaluation-Rebellion.
} 
instance, in a number of late medieval German peasant uprisings - of which there were many between the 145 os and 1526 - negotiability of coin values and the ability of some actors to inflict "unjust" or unfair coin exchange rates upon the other party in a deal were highlighted as major causes for worry and unrest. Very often the bailiff, when it came to the payment of seigniorial dues, would simply refuse a small-change coin such as a penny (around 1400 worth $1 / 240$ th or $1 / 252$ nd of a florin), heller or half-penny (1/504th of a florin or gulden) or albus ("white penny," $1 / 24$ th of a florin) at nominal value because very often lowvalue coins contained much less silver than they were supposed to, thus being considered bad, "evil" or unworthy of purchasing as much as they should. Then their market or accepted value was discounted, their intrinsic value (valor intrinsecus) being lower than their imputed nominal value decreed by the government or ruler (valor extrinsicus, valor impositus).

During the Middle Ages coins represented the main share of monetary stock. They were usually made of some precious metal with the addition of some base metal. ${ }^{17}$ Base metal had to be added, for two reasons. On the one hand, it was physically impossible to produce pure silver or gold coins. On the other hand, the varying ratio of precious to base metal within a particular coin determined its purchasing power in the market. But silver and gold were marketable commodities in their own right. There were competing claims on this resource, apart from the state, which issued the money, and the financial markets that traded in coins and precious metal. Silver- and goldsmiths were also important in the competition for silver, catering inter alia for conspicuous consumption. Adjustments to coins' physical composition had to be made frequently, as silver supply and silver prices varied considerably across time and space. The fine-tuning of monetary policy according to the needs of society and economy, as well as the fluctuations of the metal market, required very intricate techniques of metallurgy and minting.

Coins were struck in mints using quite primitive techniques. Silver and gold in the shape of old or foreign coins, raw gold and silver, bullion (ingots), jewellery, and ornaments delivered to the mint were smelted, then transformed into sausage-like pieces or bars. These were cut into thin round slices which were then imprinted with the coin's image, back and front, using a hammer and a die. There were as yet no machines or means of mechanizing parts of the process. ${ }^{18}$ Making money, i.e., the striking of coins and running a mint as

\footnotetext{
17 Spufford, Money and its Use; Grierson, Numismatics and History; and Grierson, Numismat$i c s$. An excellent recent introduction which combines historical method with numismatics and some monetary history is Klüßendorf, Münzkunde-Basiswissen. See otherwise the works referred to in $n$. 10 above.

18 Sargent and Velde, The Big Problem of Small Change.
} 
a capital-intensive, risky, but profitable big business, required hard physical work and prodigious outlets of fixed and working capital (for buildings, smelting ovens etc.). Mintmasters also had to possess considerable metallurgical and financial knowledge. Accordingly, they were usually recruited from the long-distance trading and merchant class, whose members had an intimate knowledge of the financial markets as well as the financial means to run such a high-profile business as a royal or princely mint.

In the early and high Middle Ages, small-change coins, usually pennies, were imprinted only on one side, because they were too thin and too small to bear a double imprint. In the German lands they went by the name of Hohlpfennige (literally "hollow pennies") or bracteates. These circulated in a relatively restricted area, usually tied to a particular town or city with a weekly market. Archaeological and circumstantial evidence suggests that often when they were used they were not meant to be counted (payment by tale) but rather weighed (payment by weight), particularly because there could be a considerable variance in this coin type's weight. They were meant to be carried around and handed over in transactions using small leather bags. These coins were frequently recalled and thus limited in terms of temporal validity, and were unknown in Britain, France, Spain, Italy, and the Low Countries.

In later periods, as techniques developed, the European economy grew, and the hunger for cash expanded, larger denominations were struck, from shillings and groats (grossus, pl. grossi) up to the florins (fiorino, Genovino, Rheinische gulden), whose design was more elaborate, often showing images of the ruler on one face and some other symbolic depiction of state power on the other. However, hohlpfennige or bracteates of the old type remained in circulation in Saxony and many parts of central Europe into the 16th century. They often gave cause for unrest and anger, as their value and according purchasing power fluctuated heavily and could not be established accurately. This gave rise to negotiation, cheating and disputes..$^{19}$ Depending upon the fineness of the material and the weight and shape of the coins, much more information could be impressed, especially when coins became larger. Muslim denarii or dirhams in the 8th and 9th centuries are said to have contained more than 200 letters or characters at times; early modern coins could be much more primitive and less complex as containers of information. This should caution us not to assume linearity in the technological process or progress of making coins: there were huge variations not only over time but also space, in terms of technique and quality of the circulating means of exchange. Accordingly, coins could convey 
significant amounts of verbal/literal and numerical information at times, at least those that were larger or full-bodied and of high value.

While it is obviously impossible (and largely speaking unfeasible) to determine the amount of money in circulation or the relation between coins (cash) and cashless means of payment (credit, velocity of money) in the overall monetary stock at any point in time or for any society or economy during the Middle Ages, coins represented the major part of the total money supply. Cashless payment methods such as the bill of exchange and credit transactions became increasingly important towards the later Middle Ages but remained restricted, in terms of use and usability, to an extremely small and very exclusive "club" of merchants who were part of the network of trust, commitment, acceptance, and mutual relationship. ${ }^{20}$ If we define money as a general-purpose instrument or means of exchange, the bill of exchange certainly does not qualify. So the monetary stock was, during the Middle Ages, almost entirely represented by gold, silver, and copper embodied in coins; towards the later Middle Ages and during the 16th century both high-value or full-bodied money and small change tended to be dominated by silver. Gold florins fell more and more out of daily use but remained important for notation of obligations, payments, and dues, i.e., as a money of account (such as the German reichsthaler after 1500, which was never minted as an actual coin). The dawn of the modern period was also the dawn of the Silver Age. Gold and silver had competing uses for different purposes, such as jewellery, silverware, and other means of conspicuous consumption and saving. This did not exactly facilitate a stable or even secure supply of liquid means of circulation. In fact, it created numerous economic and social problems that were quite characteristic of the pre-modern age.

During the early Middle Ages the only coin that existed physically was the penny or denarius (d). Only in later years, by the 13th century, would larger coins or multiples of the penny be minted, i.e., struck as actual physical objects. In the wake of the 794 monetary reform of Charlemagne, it represented the 12th part of a shilling and $1 / 24$ oth of a pound and initially also the florin, or (after the florin-groat ratio was increased from 1:20 to 1:21) the 252th part of a florin in the Germanic and Bohemian lands. Neither the pound nor the shilling, however, actually existed physically, i.e., as coins. They merely represented a standard or money of account: a means contemporaries used to reckon with ("ghost money"). The Middle Ages thus had a clear understanding or monetary concept of virtual money, which is something very modern. Just recall that today the amount of virtual or book money in circulation far surpasses the

Denzel, Handbook, introduction. 
amount of US dollars physically available in coins and bank notes both in as well as outside the United States! Here the boundaries between money and credit became fluid.

In medieval times, at least in the urban commercial environment, people employed at least three different concepts of money. ${ }^{21}$ One was the moneta effectiva, or the coins actually spent and handed over in transactions. These could be various, sometimes to a bewildering degree. ${ }^{22}$ Another was moneta numeraria, or the specification of a certain currency for a certain transaction. The third or most general concept was the monete di conto or money of account, i.e., the general accounting system or conventions to which the social and economic system, the "nation" or country or community, subscribed and on the basis of which contracts were sealed and property rights and claims on economic resources framed. This money of account was usually the librasolidus system at 20 solidi to the pound or 21 groats to the florin or gulden in the German lands towards the end of the Middle Ages (the groat being akin to the shilling in terms of its position on the nominal or monetary scale).

From the 13th century onwards, with the quickening of economic life after the commercial revolution, larger coins were minted to represent multiples of the denarius. These went by the name of groat (meaning simply "big"), groot in Dutch, and groschen in German, sometimes denoting multiples of 12 such as the shilling (Latin solidus, abbreviated in the sources as s. or sol.), but often a different amount, such as four or eight pennies in Scotland, England, or elsewhere. In France, the first gros tournois at 12 deniers containing 4.22 grams of silver were produced from 1266 on. In England, groats were minted beginning in 1279, and on a more sustained basis in 1351. In the German/central European lands the Meißner Groschen (groats from Meissen in Saxony) and the Prague groats (Prager or Böhmische Groschen) became commonplace after discoveries of rich silver deposits in the central European mining region around the Erz Mountains (Erzgebirge) in Saxony and Bohemia. ${ }^{23}$ Shortly before that, in 1252 , gold coins to the value of one pound or libra (at 20 solidi or shillings) had begun to be minted in Florence and Genoa. They contained 3.54 and 3.53 grams of gold respectively and attained the name of florin after the former, the

21 Lane and Mueller, Money and Banking. Körner's Luzerner Staatsfinanzen, about Swiss state finance towards the end of the Middle Ages, also contains an extremely lucid account of the variety of shapes that money could take.

22 Rössner, Deflation, chs. 3 and 4.

23 On the early Meissen and Bohemian groats, see, e.g., Castelin, Grossus Pragensis; Schwinkowski, Das Geld- und Münzwesen Sachsens; Krug, Die meißnisch-sächsischen Groschen; Haupt, Sächsische Münzkunde; Goerlitz, Staat und Stände. 
place they had been invented. The Venetian ducat, at 3.545 grams of gold, corresponded to this standard and monetary segment; it remained in existence as a "European" currency standard by denomination until very recently. ${ }^{24}$

The purchasing power of a denarius or penny could be quite high. In the 7 th or 8th century, it might have bought you as much as one sheep. But even in the later period, pennies could bear a high purchasing power, especially during times of deflation and economic depression in the urban market economies when the price level for consumables was low and unemployment high. Around 1350 the daily wage of a labourer in England could be as low as two denarii or pennies per day. ${ }^{25}$ Around 1500 in the South German lands, maidservants earned as little as five florins or 1,26od per annum at the nominal exchange rate of $252 \mathrm{~d}$ to the florin (and $12 \mathrm{~d}$ to the shilling or groat, with the florin exchanging at 21 groats after the 149 os when the ratio had been increased from 20 to 21 groats to the florin). ${ }^{26}$ At a supposed working year of 260 days this worked out to just under five pence per day. But the monetary payment of wages was topped up by non-monetary components, including housing, clothing, and food. This perhaps illustrates best the slightly different position and role money had in society then compared to nowadays.

Throughout the Middle Ages the shape, size, and form of the penny and its fractions such as the heller (German half-penny), mite, and farthing (onequarter of a penny, England) varied from region to region and across countries, time, and space. As we have seen above, around 1500 the Holy Roman Empire alone had 500 open mints and only slightly fewer political authorities or states with the right to mint coins. This means that at any one point in time and space any individual would have in hand a plethora of different coins of diverse regional origin, age, and denomination. The varieties available could easily number several hundred. As coins often travelled long distances and frequently crossed political borders, the composition of the monetary stock was varied and inhomogeneous. Especially in the case of small change used in day-to-day transactions, coins circulated by weight, not tale, meaning that contemporaries often tried to check coins' purchasing power first before accepting them in transactions. (This power was derived from the amount of silver or gold the coins contained.) At least this is the impression which the rich documentation from the age of the post -14 th century peasant wars shows us: nearly every one

\footnotetext{
24 Stahl, "Making of a gold standard".

25 Sargent and Velde, Big Problem, p. 48, table 4.1.

26 Meticulously documented in the voluminous empirical survey Dirlmeier, Untersuchungen zu Einkommensverhältnissen und Lebenshaltungskosten.
} 
of these uprisings was preceded by complaints about "evil" coins and authorities refusing to accept small-denomination coins at face value. ${ }^{27}$

Towards the end of the Middle Ages in the German lands, "native" coins, i.e., those struck by the local political authority, usually represented a minority of the total coin stock in circulation: around 20 to 30 per cent at best, according to the best numismatic evidence we have provided on the basis of coin hoards. ${ }^{28}$ Encountering and using foreign coins hence represented a daily and very familiar experience for medieval people at all levels of coin use, from the small-change pennies to the medium-range groschen up to the full-bodied silver and gold thalers and florins. Moreover, old coins coexisted alongside new ones. This created many economic and social problems, particularly within the medium- and low-size value spectrum, ${ }^{29}$ where the intermingling of old, new, foreign, and native coins created difficulties of valuation and comparison which led to conflicts over small-change coin use in day-to-day transactions. Full-bodied high-value coins tended to be more stable in terms of the silver or gold they contained; they were debased much less often than small-change coins, and contained relatively more precious metal relative to their extrinsic value or official purchasing power. Small-change coins had an inbuilt fiduciary component by being worth much less, intrinsically, than they should be, extrinsically.

In the Middle Ages rulers frequently "recalled" existing coins by ordering that all existing money be brought into the princely mint to be recoined into new money, with the new issue usually containing less precious metal than previous ones. Simultaneously the old coins were declared unlawful. This was a standard technique in the set of options available for the politics of minting. For a long time, it remained a generally accepted means of raising revenue for the ruler or state without having to obtain consent from the estates or magnates of the realm (parliament). European monetary history, when broken down into different coin types, seems to suggest that debasement was disproportionately more often an issue in the case of small- and medium-sized currencies; gold nobles and silver florins were coins which kings and their mintmasters did not usually touch when "playing around" with seigniorage, i.e., the

27 Rössner, Deflation, ch. 4.

28 See, e.g., North, Geldumlauf und Wirtschaftskonjunktur; Schüttenhelm, "Problems of quantifying the volume of money in early modern times"; Schüttenhelm, "Zur Münzprägung und Silberversorgung süddeutscher Münzstätten im frühen 16. jahrhundert”. For an application of statistical techniques to numismatic method with the aim of estimating the composition of money supply on a regional basis, see Schüttenhelm, Der Geldumlauf im südwestdeutschen Raum and Eichhorn, Der Strukturwandel. 
option of raising what was effectively an inflation tax for funds needed in times of war, etc. ${ }^{30}$

\section{What Stories Does Money Tell Us?}

The stories that money can (or cannot) tell us depend in part on the epistemic vantage points of the analysis: What question do I want to solve? Which sources can I use to answer my question? What methodology? Any sound evaluation of money as an object of study, using it as a historical source, has to engage with the methodology of numismatics. ${ }^{31}$ Ever since history began to evolve into an academic discipline in the 18th century, historians have been aware of the need to develop reliable techniques enabling them to establish the credibility and reliability of the primary sources they use in their analyses. For numismatics, this hinged upon the establishment of the metallurgical-chemical properties of the object (coin) under consideration, which could then be supplemented with contemporary corroborative evidence such as decrees, acts, and ordinances issued by the rulers and authorities behind the coins in question, in order to find out its possible "histories": how was a particular coin meant to be used? How did people use it? And so on.

If a coin is nothing more or less than a container of information, in order to retrieve or "read" this information numismatists can try to establish its weight, its precious metal content in relation to base metals or alloy, the fineness (usually in carats) of the precious metal, and subsequently its outer physical parameters (size, width). The next step is to study what is on the coin - a depiction of the ruler, or his head? Or some sort of regal insignia (sword, cross), or even a written message? It is very often the latter that most commonly enables numismatists to establish a coin's age, provenience, and authenticity. This information can only be retrieved by a simultaneous cross-check with information from the contemporary place from which the coin emerged, i.e., the mint. Usually, whenever a new type or series of coin types was minted the ruler would decree how much anyone bringing so-and-so-much silver (or gold) to his mint would get back in the shape of coins. Or the edict would say that "out of one mark of silver [a regionally varying measure, usually around 250 grams of silver of a certain fineness] strike so and so many thalers, so and so many florins, groschen, or something else." This was the mint ratio or mint price; it

$30 \quad$ Spufford, Money; Sargent and Velde, Big Problem; Sprenger, "Münzverschlechterung".

31 See works referred to in note 10 above. 
set the basic economic and monetary parameters within which market-based exchange and commerce would usually unfold. Knowledge of the imagery on coins, the iconography and other elements of stylistic variation, is also important when it comes to determining how old a particular coin is, or whether it is forged, analogous to the way the papyrologist and the palaeographer help the historian determine whether a written act, deed, or other document is genuine or not.

Enter the monetary historian and economist. To establish how many coins circulated and how much money was available in medieval and early modern Europe is well-nigh impossible, although some suggestions have been made for medieval England. ${ }^{32}$ The fact is that there is great variation between scholars' estimates of the composition of the monetary stock and the velocity of circulation of diverse types of coins that constituted it. This makes any quantification meaningless because the biggest factor in the equation goes by the name "guesswork". We know that no European ruler would ever have been able to effectively control the money supply in his kingdom or principality other than by regulating or limiting the issue of new coins, i.e., new mint runs, which sometimes meant that people needed to bring back all their old money to have it recoined. Not everyone always did so, however, as "old" money could be more valuable than new money if the latter was reduced in precious metal content, which was often the purpose of the recall. This may mean that at any one time an unknown number of old coins circulated that had not been brought back to the mint for coinage, along with an equally unknown amount of foreign but "legal tender", which made any quantitative control well-nigh impossible. Scholars have used proxies, for instance precious metal flows between world regions such as Asia and Europe or the Levant and southern Europe (Italy), to speculate about the likely development of monetary and coin supply. But obviously not all silver and gold that was shipped into and out of Europe was minted. People would use precious metal for making beakers and chalices, silver crosses for churches, jewellery, and many other things. Sometimes they would turn jewellery or other forms of plate into coins, sometimes vice versa. We know from Martin Luther's Table Talk that his wife Katharina of Bora would often have to sell some of the couple's domestic valuables when the household ran out of cash. Boundaries of uses between silver and gold as "money" and "luxury consumable" or commodity were fluid and constantly shifting. This is another reason why the quantification of the amount of money in circulation

32 See, e.g., Mayhew, "Numismatic evidence"; Mayhew, "Modelling medieval monetisation"; Mayhew, "Money supply"; Bolton, Money in the Medieval English Economy; and Allen, "Silver production". 
at any one point in the late medieval and early modern European economy is, to an extent, meaningless.

Some scholars, the present one included, have tried to quantify, if in broad and very speculate dimensions, other variables of monetary mass, such as velocity. There is little agreement about the absolute size of this, but usually scholars agree that different types of coins or "segments" of the monetized component of market exchange circulated with different velocities. High-value full-bodied gold guldens and silver thalers circulated less rapidly than a badly debased penny, farthing, or groat. The small money of the common man typically had to work harder and was used more frequently in transactions and less often for saving or storing value throughout the year. More often, if these happened to be debased bad and "evil" coins (such as the black "Oppressor's Pennies" or Schinderlinge of the Inner Austrian hyperinflation of 1459-1460), people would try to get rid of them as quickly as possible because, as we have seen above, these coins failed to fulfil one of the crucial modern purposes, i.e., to act as a safe store of value.

Money could also be a tool of politics. As we have seen above, money in the early modern age was almost always made of metal and it nearly always contained at least some amount of precious metal. ${ }^{33}$ At that time people defined their trust in money and its purchasing power in terms of what its content would actually buy. There was no such thing as a generally accepted level of trust in money's face value. People derived their trust from what was actually in these coins. That is, they tried, whenever they could, to get a better insight into each coin's intrinsic value (precious metal content) before using it in economic transaction. Low-value coins received less attention, while gold pieces were treated with considerable care, but as we have seen above, even in the context of low-level coins, disputes and conflicts arose, because coins were difficult to check but people would often know they contained much less silver than they ought to. The social conflicts and peasant uprisings of the period may thus be studied from a monetary viewpoint, yielding further important insights into the working mechanism of pre-industrial peasant and market society. ${ }^{34}$

In the early modern period coins' metal was usually silver and copper. And that was a big problem. High-value coins were made either from gold or silver with only a little addition of base metals. The value of the gold or silver contained in them came close to their face value or officially fixed coin exchange rate. The minor difference between their face value and the market value or 
purchasing power of the precious metal they contained covered the costs of minting (brassage), including rents, profits, and the wages of mintmasters and their employees, as well as the regal monopoly of the state (seigniorage) to issue money. ${ }^{35}$ Below them came the medium-sized coins, most commonly called groats or batzen, which by and large still had a fairly high content of silver so as to make them trustworthy enough for people to accept at face value. At the third level, the whole story becomes tricky. Small-denomination coins such as pennies and hellers were extremely costly to make relative to their value. And this led to the fact that they usually contained much less precious metal than they were worth, at least in terms of the official exchange rate. Here we have a modern or fiduciary theory/understanding of money that was inserted within a model - or the generally accepted consensus and understanding of the majority of the population - that derived the purchasing power of coined money from the value of the precious metal actually contained in it.

Minting or striking coins was physically demanding work. It was also costly, and as we have seen above, it was usually an activity carried out by professional entrepreneurs (mintmasters). Small, rounded pieces cut from large sausagelike chunks of solid metal had to be hammered out piece by piece. This was an operation to be repeated hundreds of thousands of times, especially if more small change was minted. In 1500 in southern Germany, 100 kilograms of silver would have provided the raw material for about 1.7 million hellers or 637,000 pennies containing between one and two grams of pure silver - but only 3,571 silver thalers (one thaler being equivalent to one rhinegulden or gold florin in value) containing about 27 grams of silver each, which were accordingly heavier. Clearly it was cheaper, that is, more cost-efficient, for the mintmaster, who was usually a merchant or other entrepreneur, to strike full-bodied coins. The same amount of precious metal could be processed with less input of work, hours of labour for the mintmaster and his workers, rent charges for mint and physical equipment, etc. The physical tasks and effort expended were the same regardless of whether a heller, florin, or thaler was struck. The absolute costs of striking a coin were - with only minor differences - the same for all. It is not difficult to guess where producers' preferences lay. Low-value coins were often debased more than they should have been in order to recoup the costs of minting them. Sometimes the mintmaster and his ruler would even form secret agreements to the effect that the former would give out coins that contained much less silver or gold than they should, according to official stipulation. The people who came to the mint, faithful to the official decree 
that stipulated "you will get back so many shillings for so many kilos of silver" would effectively be cheated, and the ruler and his mintmaster could pocket the gain. It is quite obvious that this game could only be played while the public failed to realize the deceit. This could take as long as half a year or even more, until reliable knowledge emerged and word had spread as to the coins' true precious metal content and value had spread. The French kings used this technique as a means of financing their near-endless wars in the mid-14th century. ${ }^{36}$ But we also know that these measures could be effective in the short run only, as people would find out after some time and adjust their expectations of the debased coins downwards. This triggered repeated and sometimes massive inflations in France around the 1350s.

However, full-bodied coins were of no use to the common man, who needed mostly pennies, groats, and hellers, if he or she entered the market. A thaler (from which the dollar got its name) such as the one minted by the Saxon dukes and electors after 1500 and in Bohemian Joachimsthal (today Jáchymov in the Czech Republic) in the $15^{20}$ os had at that time a purchasing power roughly comparable to modern high-denomination currency, such as the rarely seen 50o-euro banknote. Unless one is engaged in high-value trade with the aim of concealing sales and perhaps avoiding tax, a $€_{5}$ oo note has no practical exchange or use value. No shop or petrol station will currently accept notes of a higher denomination than 200 euros (even though this refusal is not legal and cannot be sanctioned: $€_{5}$ oo notes still represent legal tender, as does all euro currency). Thalers and Rhenish florins were used by people in larger transactions such as house sales: a good-sized farm in Saxony around 1500 could be had for 100 or 200 florins. The bulk of day-to-day transactions in the common man's market economy rested on the use of medium- and small-denomination coins. Small-denomination coins, however, were usually minted at a loss. At least this is what surviving mint documents from the period and calculation exercises would suggest. ${ }^{37}$ This explains why so many rulers, princes, and kings were reluctant to strike small change such as pennies, hellers, and farthings. There was a lot of money to be made in making money when the mint was used as a profit-making enterprise (by the mintmaster) or to reap a windfall or inflation tax gain by raising seigniorage and brassage; there was, conversely, more of a loss in the making of small-change coins, which often did not bear out the costs of production.

36 Spufford, Money.

37 Munro, "Münzkosten”; Sprenger, “Münzverschlechterung”, p. 132. 
There were lots of people with a stakeholder interest in the business of making coins, as is demonstrated by the voluminous range of expert references, monetary ordinances, and other state documentation that was produced in preparation for, during, and in the wake of major currency reforms at territorial, imperial, and imperial circle (Reichskreise) levels. In fact, this type of inflationary legislation after $c$.A.D. 1400 pays lively testimony to the rise of the early modern bureaucratic state. ${ }^{38}$ Very often monetary authorities such as princes, kings, dukes, and counts covered their loss by heavily debasing small coins, putting them into circulation far below their face value. ${ }^{39}$ People who were offered underweight coins naturally viewed them very sceptically. They could never be sure if they would be able to use them at face value again in future transactions. This greatly reduced these coins' functionality as a means of storing wealth for investment or future transactions. And that is where all the problems began: as we have seen above, many a medieval German peasant uprising came about at least in part because the small-change coins were perceived to be bad and represented a problem, especially when it came to relations between peasants and lords, and dues paid by the former to the latter.

\section{Conclusion and Areas of Further Research}

Coins can thus tell us a variety of stories: about magic, superstition, economic and monetary relationships, and how, for instance, it is possible to explain inflation or deflation by knowing something about the quantity of coins that circulated. They also reveal something of the politics of "making money": of minting, running a mint, or charging seigniorage, of regalian rights which usually dictated that a prince, duke, or king was to be given a fixed share of everything that came from underneath "his" soil, or out of "his" mountain. Money could also give rise to disputes and contested claims, for instance due to the uncertainty and principal re-negotiability of coin exchange rates, which gave rise to considerable conflict and social unrest. Money in this way also reflected asymmetrical power relationships between lords and the men who had to pay their taxes and dues and whose possibly hard-earned monies would not be accepted at face value by the ruling authorities. Of course - but this hardly bears mentioning - money could also be the cause of massive economic inequality.

38 Volckart, Eine Währung; Rössner, Deflation, ch. 3 for provincial and territorial currency reforms in the 15 th and 16 th centuries.

Rössner, Deflation, passim, esp. ch. 4; and Sargent and Velde, Big Problem. 
Thus money is much more - and less - than an instrument of exchange. It has been invested with cultural and moral meaning. It has always carried social meaning and been a great source of inequality, on different levels, as well as a bearer of messages which other more standard primary sources will never convey to the historian. They represent an invaluable addition to the rich range of sources for historians of objects who should, when evaluating new trends, give some effort to the rigorous methodological training associated with the discipline of numismatics. Together with some monetary and economic history, spiced with a pinch of cultural turn, with a heavy dose of straight-edge historical method as seasoning, this should make for a tasty and interesting meal.

\section{Bibliography}

Ago, R., Gusto for Things: A History of Objects in Seventeenth-Century Rome, Chicago, 2013 .

Allen, M., "Silver production and the money supply in England and Wales, 1086-c.1500", Economic History Review, 2nd ser., 64 (2011), 114-31.

Appadurai, A. (ed.), The Social Life of Things: Commodities in Cultural Perspective, Cambridge, 1986.

Attfield, J., Wild Things: The Material Culture of Everyday Life, Oxford, 2000.

Beckert, S., Empire of Cotton: A New History of Global Capitalism, London, 2015.

Bloch, M., The Royal Touch: Sacred Monarchy and Scrofula in England and France, and ed., London, 2015.

Bolte, J., et al. (eds.), Handwörterbuch des Deutschen Märchens, Berlin, 1934.

Bolton, J.L., Money in the Medieval English Economy 973-1489, Manchester, 2012.

Castelin, K., Grossus Pragensis. der Prager Groschen und seine Teilstücke 1300-1547, 2nd ed., Braunschweig, 1973 .

Cipolla, C.M., “Economic depression of the Renaissance?", Economic History Review, n.s. 16 (1964), 519-24.

Day, J., "The great bullion famine of the fifteenth century", Past \& Present 79 (1978), 354.

Day, J., "The question of monetary contraction in late medieval Europe," in. J.S. Jensen (ed.), Coinage and Monetary Circulation in the Baltic Area, c.1350-c.1500, Copenhagen, 1982, 12-29.

Denzel, M.A., Handbook of World Exchange Rates, 1590-1914, Farnham, 2010.

Dirlmeier, U., Untersuchungen zu Einkommensverhältnissen und Lebenshaltungskosten in oberdeutschen Städten des Spätmittelalters (Mitte 14.-Anfang 16. Jh.), Heidelberg, 1978. 
Ehrman, B.D., The Lost Gospel of Judas Iscariot: A New Look at Betrayer and Betrayed, Oxford, 2006.

Eichhorn, H., Der Strukturwandel im Geldumlauf Frankens zwischen 1437 und 1610. Ein Beitrag zur Methodologie der Geldgeschichte, Wiesbaden, 1973.

Findlen, P. (ed.), Early Modern Things: Objects and their Histories, 1500-180o, Abingdon, 2013.

Friedensburg, F., Münzkunde und Geldgeschichte der Einzelstaaten des Mittelalters und der Neueren Zeit, Munich, 1926.

Gerhard, H.-J., "Miszelle: neuere Deutsche Forschungen zur geld- und Währungsgeschichte der Frühen Neuzeit. Fragen - Ansätze - Erkenntnisse", Vierteljahrschrift für Sozial- und Wirtschaftsgeschichte 83 (1996), 216-30.

Gerhard, H.-J., "Ein schöner garten ohne zaun. Die währungspolitische Situation des Deutschen Reiches um 16oo", Vierteljahrschrift für Sozial- und Wirtschaftsgeschichte 81 (1994), 156-77.

Gerhard, H.-J., "Ursachen und Folgen der Wandlungen im Währungssystem des Deutschen Reiches 1500-1625. Eine Studie zu den Hintergründen der sogenannten Preisrevolution", in E. Schremmer (ed.), Geld und Währung vom 16. Jahrhundert bis zur Gegenwart, Stuttgart, 1993, 69-84.

Goerlitz, W., Staat und Stände unter den Herzögen Albrecht und Georg 1485-1539, Berlin, 1928.

Graeber, D., Debt: The First 5,0oo Years, New York, 2015.

Grassby, R., "Material culture and cultural history", Journal of Interdisciplinary History 35 (2005), 591-603.

Grierson, P., Numismatics, Oxford, 1975 .

Grierson, P., Numismatics and History, London, 1951.

Hamling, T., and Richardson, C. (eds.), Medieval and Early Modern Material Culture and Its Meanings, Farnham, 2010.

Handley, S., Sleep in Early Modern England, New Haven, 2016.

Hart, K., "Heads or tails? two sides of the coin", Man 21 (December 1986), 643-47.

Harvey, K. (ed.), History and Material Culture: A Student's Guide to Approaching Alternative Sources, Oxford, 2009.

Haupt, W., Sächsische Münzkunde, Vol. I: Text, Berlin, 1978.

Hiller, H., Lexikon des Aberglaubens, Munich, 1986.

Hoskins, J., "Introduction", in J. Hoskins (ed.), Biographical Objects: How Things Tell the Stories of People's Lives, New York, 1998, 1-24.

Jevons, W.S., Money and the Mechanism of Exchange, London, 1876.

Johnson, M., An Archaeology of Capitalism, Cambridge, Mass., 1996.

Kingery, W.D. (ed.), Learning from Things: Method and Theory of Material Culture Studies, Washington, D.C., 1996.

Klüßendorf, N., Münzkunde - Basiswissen, Hanover, 2009. 
Knapp, G.F., Staatliche Theorie des Geldes, Munich, 1905.

Körner, M., Luzerner Staatsfinanzen 1415-1798. Strukturen, Wachstum, Konjunkturen, Lucerne, 1981.

Krug, G., Die meißnisch-sächsischen Groschen 1338 bis 1500, Berlin, 1974.

Lane, F.C., and Mueller, R.C., Money and Banking in Medieval and Renaissance Venice, Vol. I: Coins and Moneys of Account, Baltimore, 1985.

Lopez, R.S., The Commercial Revolution of the Middle Ages, 950-1350, Cambridge, 1976.

Luschin von Ebengreuth, A., Allgemeine Münzkunde und Geldgeschichte des Mittelalters und der Neueren Zeit, 2nd ed., Munich, 1926.

MacGregor, N., A History of the World in 100 Objects, London, 2012.

Mayhew, N.J., "Modelling medieval monetisation”, in R.H. Britnell and B.M.S. Campbell (eds.), A Commercialising Economy: England 1086 to c.13oo, Manchester, 1995, 55-77.

Mayhew, N.J., "Money supply, and the velocity of circulation in England, 1300-1700", Economic History Review, 2nd ser., 48 (1995), 238-57.

Mayhew, N.J., "Numismatic evidence and falling prices in the fourteenth century", Economic History Review, 2nd ser., 27 (1974), 1-15.

Mayhew, N.J., "Prices in England, 1170-1750", Past \& Present 219 (2013), 3-39.

Mehler, N., "The archaeology of mercantilism: clay tobacco pipes in Bavaria and their contribution to an economic system", Post-Medieval Archaeology 43 (2009), 261-81.

Miskimin, H., The Economy of Later Renaissance Europe, 146o-16oo, Cambridge, 1977.

Miskimin, H., "Monetary movements and market structure: forces for contraction in fourteenth- and fifteenth-century England", Journal of Economic History 24 (1964), 470-9o.

Munro, J.H., "The monetary origins of the 'price revolution' ", in D.O. Flynn, A. Giráldez, and R. von Glahn (eds.), Global Connections and Monetary History, 1470-180o, Aldershot, 2003, 1-34.

Munro, J.H., “Münzkosten”, in M. North (ed.), Von Aktie bis Zoll. Ein historisches Lexikon des Geldes, Munich, 1995, 263.

North, M., Das Geld und seine Geschichte. Vom Mittelalter bis zur Gegenwart, Munich, 1994 .

North, M., Geldumlauf und Wirtschaftskonjunktur im südlichen Ostseeraum an der Wende zur Neuzeit (1440-1570). Untersuchungen zur Wirtschaftsgeschichte am Beispiel des Großen Lübecker Münzschatzes, der norddeutschen Münzfunde und der schriftlichen Überlieferung, Sigmaringen, 199 o.

North, M., Kleine Geschichte des Geldes. Vom Mittelalter bis heute, Munich, 2009.

Opie, I., and Tatem, M. (eds.), A Dictionary of Superstitions, Oxford, 1989.

Pagels, E., and King, K.L., Reading Judas: The Gospel of Judas and the Shaping of Christianity, London, 2008.

Peacock, M., Introducing Money, London, 2013.

Reden, S. von, Money in Classical Antiquity, Cambridge, 2011. 
Riello, G., Cotton: The Fabric That Made the Modern World, Cambridge, 2013.

Rittmann, H., Deutsche Geldgeschichte 1484-1914, Munich, 1975.

Rössner, P.R., Deflation - Devaluation - Rebellion. Geld im Zeitalter der Reformation, Stuttgart, 2012.

Rössner, P.R., "Monetary theory and cameralist economic management, c.1500-1900 A.D.", Journal for the History of Economic Thought 40:1 (2018), 99-134.

Rublack, U., "Matter in the material Renaissance", Past \& Present 219 (2013), 41-85.

Sargent, T.J., and Velde, F.R., The Big Problem of Small Change, Princeton, 2003.

Schremmer, E., “Über 'stabiles Geld'. Eine wirtschaftshistorische Sicht,” in E. Schremmer (ed.), Geld und Währung vom 16. Jahrhundert bis zur Gegenwart, Stuttgart, 1993, 9-44. Schrötter, F., "Das Münzwesen des Deutschen Reichs von 1500 bis 1566", Jahrbuch für Gesetzgebung, Verwaltung und Volkswirtschaft 35 (1911) and 36 (1912), repr. in F. Schrötter, Aufsätze zur deutschen Münz- und Geldgeschichte des 16. bis 19.Jahrhunderts (1902-1938), ed. B. Kluge, Leipzig, 1991, 3-76.

Schüttenhelm, J., Der Geldumlauf im südwestdeutschen Raum vom Riedlinger Münzvertrag 1423 bis zur ersten Kipperzeit 1618. Eine statistische Münzfundanalyse unter Anwendung der elektronischen Datenverarbeitung, Stuttgart, 1987.

Schüttenhelm, J., "Problems of quantifying the volume of money in early modern times: a preliminary survey", in E.H.G. Van Cauwenberghe (ed.), Precious Metals, Coinage and the Changes of Monetary Structures in Latin-America, Europe and Asia (Late Middle Ages - Early Modern Times), Leuven, 1989, 83-98.

Schüttenhelm, J., "Zur Münzprägung und Silberversorgung süddeutscher Münzstätten im frühen 16. Jahrhundert", in W. Kroker and E. Westermann (eds.), Montanwirtschaft Mitteleuropas vom 12. bis 17. Jahrhundert. Stand, Wege und Aufgaben der Forschung, Bochum, 1984, 159-69.

Schwinkowski, W., Das Geld- und Münzwesen Sachsens. Beiträge zu seiner Geschichte, Dresden, 1918.

Sprenger, B., Das Geld der Deutschen. Geldgeschichte Deutschlands von den Anfängen bis zur Gegenwart, 3rd ed., Paderborn, 2003.

Sprenger, B., "Münzverschlechterung, Geldmengenwachstum und Bevölkerungsvermehrung als Einflußgrößen der sogenannten Preisrevolution im 16. und beginnenden 17. Jahrhundert in Deutschland", in: K.H. Kaufhold and F. Riemann (eds.), Theorie und Empirie in Wirtschaftspolitik und Wirtschaftsgeschichte. Wilhelm Abel zum 8o. Geburtstag, Göttingen, 1984, 127-44.

Spufford, P., Money and Its Use in Medieval Europe, Cambridge, 1988.

Spufford, P., Power and Profit: The Merchant in Medieval Europe, London, 2002.

Stahl, A., "The making of a gold standard: the ducat and its offspring, 1284-2001", in J. Munro (ed.), Money in the Pre-Industrial World: Bullion, Debasements and Coin Substitutes, London, 2012, 45-62. 
Suhle, A., Deutsche Münz- und Geldgeschichte von den Anfängen bis zum 15. Jahrhundert, 8th ed., Berlin, 1975.

Volckart, O., Eine Währung für das Reich die Akten der Münztage zu Speyer 1549 und 1557 (=Deutsche Handelsakten des Mittelalters und der Neuzeit, Vol. 23), Stuttgart, 2017.

Westermann, E., "Zur spätmittelalterlichen Depression der europäischen Montanwirtschaft. Stand und offene Fragen der Forschung", in R. Tasser and E. Westermann (eds.), Der Tiroler Bergbau und die Depression der europäischen Montanwirtschaft im 14. und 15. Jahrhundert, Innsbruck, 2004, 9-18. 